\title{
PARTISIPASI POLITIK DALAM PEMILU LEGISLATIF 2014 DI KABUPATEN ACEH BARAT PROVINSI ACEH
}

\author{
Said Fadhlain'), Andi Sayumitra ${ }^{2)}$ \\ ${ }^{1,}$ Fakultas Ilmu Sosial dan Ilmu Politik, Universitas Teuku Umar \\ ${ }^{2,}$ Fakultas Ilmu Sosial dan Ilmu Politik, Universitas Teuku Umar \\ Email: syed_0570@yahoo.co.id
}

\begin{abstract}
Election is one form of political participation as the embodiment of the people's sovereignty, because at the time of the election that, the people become the most decisive for the political process in the country by providing direct voice in the voting booth. 2014 elections in Aceh in addition to the 12 national parties (Parnas) involves three local parties (parlok) that the Aceh Party (PA), Aceh National Party (PNA), and the Aceh Peace Party (PDA). This amount is less than the elections in 2009 involving six parties lokal.Sikap voters in West Aceh related to the 2014 election of participation and measured their perceptions of penyelenggaraannya.Mayoritas voters (75\%) participate due to personal consciousness. Perception approval of voters to (1) the institution organizing the elections are independent and free of intervention, (2) the 2014 election is held directly, public, free, confidential, honest and fair, (3) the 2014 election held democratically, procedural, transparent and accountable, (4) the government's position and his staff maintain the integrity and neutrality, and (5) the 2014 election is to protect and safeguard the equal rights of voters, respectively 53\%, 43\%, 46\%, 46\% and 48\%. In organizing the 2009 elections, respondents slightly more select local parties (55\%) compared to the national party (45\%). In contrast to the 2014 election, respondents were much more choose national parties (63\%) compared to local parties (37\%). Respondents came 65\% of men and 35\% wanita.Usia respondents ranged between 18-69 years with an average of 37 years. The average income of Rp. 2.081 million, -. Television is still the main source for the voters (43\%) in the search for information related to electoral 2014. Sisanya as much as $22 \%$ and $19 \%$ seek information via the Commission and the organizers at the village level.
\end{abstract}

Keywords: Political Participation, Legislative Election, Local Party, National Party

\section{PENDAHULUAN}

Pasca musibah gempa Tsunami 26 Desember 2004, kedatangan para relawan kemanusiaan dari berbagai penjuru dunia telah memulihkan kembali infta struktur dan supra struktur kehidupan masyarakat di beberapa kabupaten dan kota di Aceh. Selanjutnya, beberapa bulan kemudian tanggal 15 Agustus 2015, ditanda-tanganinya MOU Helsinki anatara pihak pemerintah Republik Indonesia dan Gerakan Aceh Merdeka, yang menandai berakhirnya konflik yang berkepanjangan di Aceh. Suasana kondusif yang terus berlangsung, menempatkan Aceh untuk kembali menata dan menjalankan aktifitas pembangunan diberbagai bidang kehidupan.

Undang-Undang Pemerintahan Aceh No 11 tahun 2006, sebagai implementasi butirbutir MOU Helsinki, memberikan paradigma baru dalam kehidupan pembangunan politik di Aceh. Yaitu adanya penyerapan demokrasi lokal untuk pertama kali (pasca Reformasi 1998), dilaksanakan dalam pemilihan umum legislatif. Pelaksanaan pemilu legislatif 2009 di Aceh, selain dikuti oleh Partai Nasional (Parnas), juga Partai Lokal (Parlok). Pemilu 
Legislatif merupakan salah satu bentuk partisipasi politik sebagai perwujudan dari kedaulatan rakyat, karena pada saat pemilu itulah, rakyat menjadi pihak yang paling menentukan bagi proses politik di suatu negara dengan memberikan suara secara langsung dalam bilik suara. Pemilu legislatif juga sebagai sarana untuk menhasilkan wakil rakyat yang aspiratif, berkualitas, serta penuh tanggung jawab dalam rangka mewujudkan kesejahteraan rakyat. Pemilu legislatif 2014 di Aceh selain diikuti 12 partai nasional (parnas) juga melibatkan 3 partai lokal (parlok) yaitu Partai Aceh (PA), Partai Nasional Aceh (PNA), dan Partai Damai Aceh (PDA). Jumlah ini lebih sedikit dibanding pada saat berlangsungnya Pemilu Legislatif 2009 yang melibatkan 6 partai lokal yaitu (Partai Aceh/PA, Partai Rakyat Aceh/PRA, Partai Suara Independen Rakyat Aceh/SIRA, Partai Aceh Aman Sejahtera/PAAS, Partai Bersatu Aceh/PBA, Partai daulat Aceh/PDA).

Keikut sertaan tiga tiga partai lokal itu pun tidak benar-benar partai baru. Partai Nasional Aceh, misalnya, merupakan perpecahan dari Partai Aceh, sementara Partai Damai Aceh merupakan perubahan nama dari Partai Daulat Aceh karena tak memenuhi ambang batas electoral threshold. Keikut-sertaan Partai Lokal dalam sejarah Pemilu Legislatif di Indonesia, khususnya di Aceh, memiliki landasan yuridis berlangsung pada pelaksanaan pemilihan umum legislatif pada tanggal 9 April 2009. Jika dilihat dari pelaksanaan Pemilu Legislatif tahun 2009 (sebanyak 36 Partai nasional), maka jumlah partai poltik nasional (PARNAS) yang ikut pada pemilu legislatif 2014 mengalami penurunan yang signifikan yaitu sebanyak 12 partai nasional (Partai Nasional Demokrat/P-NASDEM. Partai Kebangkitan Bangsa/PKB, Partai Keadilan Sejahtera/PKS, Partai Demokrasi Indonesia Perjuangan/PDIP, Partai Golongan Karya/P-GOLKAR, Partai Gerakan Indonesia Raya /PGERINDRA, Parta Demokrat/PD, Partai Amanat Nasional/PAN, Partai Persatuan Pembangunan/PPP, Partai Hati Nurani Rakyat/P-Hanura, Partai Bulan Bintang/PBB, Partai Keadilan dan Persatuan Indonesia/PKPI).

Agenda rutin pemilu legislatif 2014 bagian dari sistem demokrasi prosedural, dimana diamanahkan dalam UUD 1945 sebagai wujud pelaksanaan kedaulatan rakyat dalam sebuah negara yang melaksanakan sistem demokrasi. Khusus UU Pemilu untuk memilih anggota legislatif diatur dalam UU No. 12 Tahun 2003 yang telah diubah dengan UU No. 10 Tahun 2008. Adanya perbedaan peserta Pemilu Legislatif 2014 di Aceh yang melibatkan 3 partai lokal dan 12 partai nasional merupakan model perwujudan sistem demokrasi tersendiri bagi pemilih yang berada di Propinsi Aceh. Pilihan pemilih pada Pemilu Legislatif 2014 akan menentukan masa depan Aceh Baru.

Forum LSM Aceh menyatakan partisipasi pemilih pada Pemilu Legislatif 2014 akan menggambarkan model transisi kekuasaan dan keterwakilan rakyat Aceh pada era mendatang. Aceh Baru digambarkan sebagai model masyarakat yang berpartisipasi dalam sistem demokrasi Indonesia dan melibatkan kelompok pada wilayah konflik untuk terlibat aktif dalam sistem pemerintah dan lembaga perwakilan pada tingkat kabupaten/kota, provinsi dan pusat. Dalam analisis politik modern, partisipasi politik merupakan hal penting dan banyak dipelajari terutama hubungannya dengan Negara berkembang. Sebagai definisi umum dapat dikatakan bahwa partisipasi politik adalah kegiatan seseorang atau kelompok orang untuk ikut serta secara aktif dalam kehidupan politik, antara lain dengan jalan memilih pimpinan Negara secara langsung atau tidak langsung, mempengaruhi kehidupan kebijakan (public policy).

Penelitian ini diharapkan menunjukkan dengan meningkatnya keterlibatan masyarakat Aceh dalam Pemilihan Umum (Pemilu) Legislatif. Proses perdamaian Aceh (pasca penanda-tanganan MOU RI dan GAM di Helsinki tahun 2005) dan sistem demokrasi menghendaki adanya keterlibatan masyarakat dalam setiap penyelenggaraan pesta rakyat 5 tahunan yang dilakukan negara. Partisipasi pemilih dalam Pemilu Legislatif 2014 di provinsi Aceh dalam hal ini di Kabupaten Aceh Barat berkaitan dengan tiga permasalahan 
utama dalam teori partisipasi politik, Pertama, masalah partisipasi politik yaitu sejauhmana individu peduli terhadap pemilu yang dilangsungkan. Apakah mereka mempunyai sikap dan persepsi yang positif terhadap proses pemilu seperti terlibat mengikuti pemilihan, berkampanye, dan sebagainya. Kedua, pilihan partai, adalah sejauhmana individu terikat kepada sesuatu partai politik. Apakah mereka mudah berpindah keanggotaan atau memilih partai lain selain partai lama yang sekian lama telah didukungnya?. Ketiga, perilaku memilih, sejauhmana partai politik menjadi identifikasi pemilih dalam pemilu legislatif?. Apakah pemilihan seseorang pemilih didorong oleh faktor dirinya sendiri atau faktor lain seperti konflik, keluarga, pemimpin, media masa, manifesto partai atau program partai, dan isu-isu tentang perdamaian Aceh dan lain-lain.

Oleh karena itu, tujuan penelitian yang dilakukan di Kabupaten Aceh Barat, yaitu:

1. Mengetahui sejauhmana sikap dan persepsi pemilih di Kabupaten Aceh Barat terkait Pemilu Legislatif 2014.

2. Mengetahui keterikatan pemilih di Kabupaten Aceh Barat pada Pemilu Legislatif 2014 terhadap Partai Lokal dan Partai Nasional.

3. Mengetahui karakteristik pemilih di Kabupaten Aceh Barat terkait Pemilu Legislatif 2014 dan faktor yang mendorong partisipasi mereka.

\section{METODE PENELITIAN}

Penelitian dilakukan di Aceh Barat.Data yang dibutuhkan berasal dari data primer dan data sekunder.Data primer berasal dari wawancara 100 responden yang tersebar pada kecamatan terpilih, Data primer lainnya berasal dari survei kepada anggota masyarakat.Data sekunder berasal dari data Pemilu Legsilatif 2014 yang dikeluarkan oleh KPU Aceh Barat. Pemilihan sampel dilakukan secara sengaja atau dikenal dengan purposive sampling berdasarkan pekerjaan utama responden.

Penelitian tentang partisipasi politik pemilih Pemilu Legislatif 2014 menggunakan penelitian kualitatif dan kuantitatif. Prosedur penelitian kualitatif menurut Moleong (2002) menghasilkan data deskriptif berupa kata tertulis atau lisan dari orang yang menjadi obyek atau responden penelitian responden. Melalui pendekatan ini diharapkan dapat mengumpulkan realita di lapangan dengan mengumpulkan data secara langsung melalui wawancara, dokumentasi dan observasi.

Menurut Whitney, penelitian deskriptif adalah pencarian fakta dengan interpretasi yang tepat dengan tujuan untuk membuat deskripsi, gambaran/lukisan, secara sistematis, faktual dan akurat mengenai fakta-fakta, sifat-sifat serta hubungan-hubungan antar fenomena yang diselidiki. Sementara penelitian kualitatif bertitik tolak dari paradigma fenomenologis yang objektivitasnya dibangun atas rumusan tentang situasi tertentu sebagaimana yang dihayati oleh individu atau kelompok sosial tertentu dan relevan dengan tujuan penelitian itu.

Tujuan penelitian kualitatif adalah bukan untuk selalu mencari sebab akibat sesuatu, tetapi lebih berupaya memahami situasi tertentu.Hasil yang diperoleh dalam penelitian deskriptif selanjutnya lebih ditekankan pada memberikan gambaran secara objektif tentang keadaan sebenarnya dari obyek yang diteliti.

Penelitian ini adalah penelitian deskriptif dengan menggunakan data kualitatif. Penelitian kuantitatif menggunakan analisis statistik deskripstif terhadap data sekunder yang terkait karakteristik sosial ekonomi, dan kondisi pemilih dan partai politik pada Pemilu Legislatif 2009 dan 2014. Analisa dilakukan sejak data awal penelusuran dan dilakukan secara terusmenerus sampai menemukan data yang sesuai dengan batasan penelitian. 
Teknik analisa data yang digunakan dalam penelitian ini adalah analisa interaktif, yaitu bahwa ketiga komponen aktivitasnya berbentuk interaksi dengan proses pengumpulan data berbagai proses siklus. Dalam bentuk ini peneliti tetap bergerak di antara tiga komponen analisis, yaitu data reduction (reduksi data), data display (sajian data) dan data conclusion drawing (penarikan kesimpulan).

\section{HASIL DAN PEMBAHASAN}

Demokrasi merupakan istilah yang dikenal luas hampir oleh semua orang dewasa. Namun saat ditanya apakah sesungguhnya demokrasi itu, maka beragam jawaban akan mengemuka, bahkan bisa bertentangan antara satu dengan lainnya. Setiap orang bisa jadi memiliki jawabannya sendiri atas apa yang menurutnya gambaran paling tepat mengenai demokrasi.

David Beetham merumuskan demokrasi dengan cara yang sederhana, yakni "sebagai sebuah prosedur pengambilan keputusan pada setiap kelompok atau masyarakat, di mana setiap anggota kelompok atau masyarakat memiliki hak yang sama untuk menyatakan pendapat dan menjadikan pandangan mereka sebagai sesuatu yang dipertimbangkan" (Beetham, 2006: 2).

Pengambilan keputusan ini diwujudkan melalui bentuk perwakilan dan sistem check and balances dalam sistem politik di Indonesia. Jadi, sederhananya demokrasi secara umum dipahami sebagai bentuk pengambilan keputusan kolektif yang ada dalam demokrasi didasarkan pada prinsip bahwa setiap anggota masyarakat harus memiliki hak yang sama dalam pengambilan keputusan yang berdampak atas diri mereka. Dalam artian demokrasi inilah yang dijadikan rujukan bagi para responden untuk memberikan penilaiannya terhadap demokrasi, kemudian kaitannya dengan pemilu legislatif 2014.

Pemilu legislatif 2014 selain sebagai saluran dan mekanisme pertarungan politik yang konstitusional dalam prinsip demokrasi modern. juga merupakan tahun politik dimana rakyat Indonesia umumnya,, masyarakat kabupaten Aceh Barat khususnya, berbondongbondong menuju bilik suara memilih wakil rakyatnya untuk keanggotaan Dewan Perwakilan Rakyat (DPR-RI), Dewan Perwakilan Daerah (DPD-RI), serta Dewan Perwakilan Rakyat Daerah (DPRD) tingkat Provinsi dan tingkat Kabupaten/Kota.

Berdasarkan dari hasil analisis data diatas menunjukkan bahwa :

\section{A. Partisipasi}

Mayoritas pemilih (75\%) berpartisipasi dikarenakan kesadaran pribadi.Selain itu panitia penyelenggara Pemilu Legislatif di tingkat desa cukup berperan dimana sebanyak 8\% pemilih ikut berpartisipasi karena ajakan dari panitia. Dalam pelaksanaan Pemilu Legislatif 2014 secara langsung, partisipasi politik adalah hal yang mempengaruhi sistem politik dalam sebuah negara yang demokratis, karena sistem politik yang demokratis tidak ada artinya tanpa adanya partisipasi politik. Oleh sebab itu, apa yang dilakukan oleh masyarakat dalam partisipasinya menunjukkan derajat kepentingan mereka. Partisipasi menjadi penting karena dapat memberikan suatu legitimasi bagi kekuasaan politik seseorang atau kelompok (partai politik). Partisipasi sangat penting bagi pembangunan diri dan kemandirian warga negara.

Melalui partisipasi, individu menjadi warga publik, dan mampu membedakan persoalan pribadi dengan persoalan masyarakat. Tanpa partisipasi, nyaris semua orang akan ditelan oleh kepentingan pribadi dan pemuasan kebutuhan orang yang berkuasa. 


\section{Alasan Partisipasi dalam Pemilu 2014}

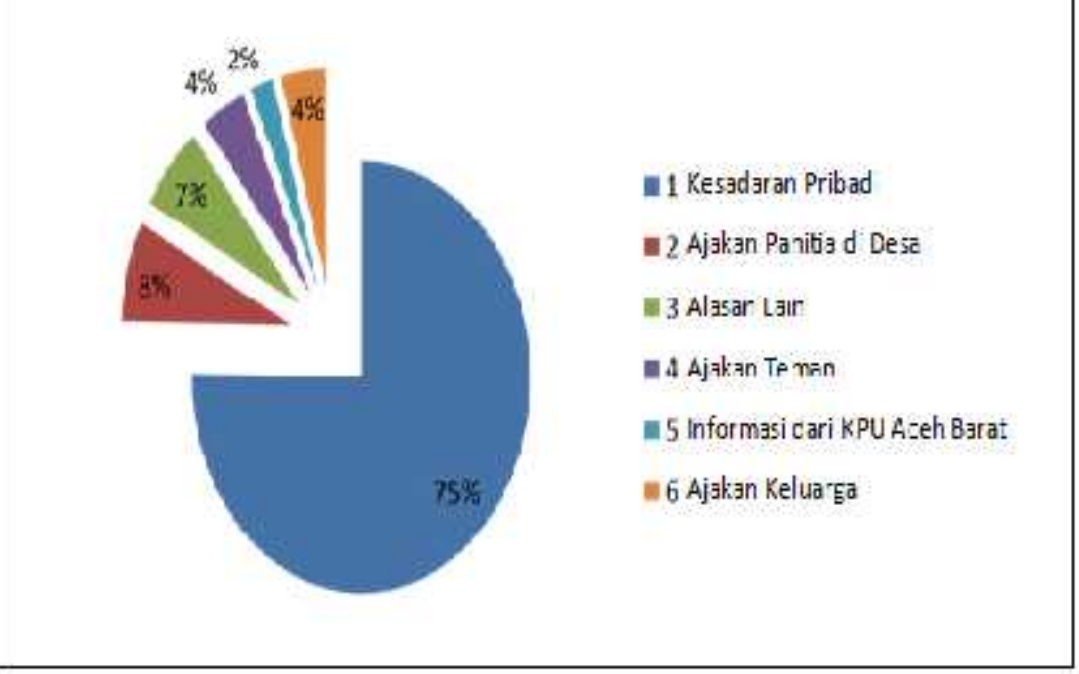

Gambar 1. Alasan partisipasi dalam Pemilu 2014

\section{B. Sumber informasi utama}

Televisi masih sumber utama bagi pemilih (43\%) dalam mencari informasi terkait Pemilu Legislatif 2014. Selain itu peran KPU dan panitia penyelenggara di tingkat desa masing-masing 22\% dan 19\% masih penting bagi pemilih dalam mencari informasi. Dalam survei yang dilakukan Lembaga Survei Indonesia (2014) tentang Survei Menjelang pemilu legislatif dan Eksekutif 2014 ditemukan bahwa sebagian besar pemilih masih sangat membutuhkan informasi tentang isu-isu kunci pemilu legislatif dan eksekutif seperti pendaftaran pemilih, dimana dan kapan memilih, dan bagaimana cara menandai kertas suara. Dari data survei ini terlihat bahwa televisi merupakan sumber informasi utama dari semua segmen pemilih.

Namun para pejabat pemerintahan di tingkat paling bawah (RT/RW, Kepala Desa/Lurah) juga di anggap sebagai sumber informasi utama khususnya bagi masyarakat yang berada di daerah pedesaan dan warga negara yang berusia tua. Dari temuan ini dapat disarankan bahwa untuk pendidikan pemilih dimasa yang akan datang dibutuhkan usahausaha yang komprehensif dengan mempergunakan kedua sumber informasi di atas televisi dan pejabat paling bawah (RT/RW, Kepala Desa/Lurah) serta sumber-sumber informasi informal lainnya dalam penyediaan informasi yang berkaitan dengan pemilu legislatif dan pemilu eksekutif.

Selain itu, temuan LSI (2014) menyatakan bahwa lima puluh persen responden menyatakan bahwa mereka masih membutuhkan banyak informasi yang berkaitan dengan semua proses Pemilu Legislatif dan Pemilu Eksekutif, sedangkan hanya 13\% dari responden yang menyatakan bahwa mereka mempunyai informasi yang cukup tentang semua proses pemilu. Temuan lainnya adalah

(1) $67 \%$ memerlukan informasi lebih banyak tentang Pendaftaran Pemilih

(2) $73 \%$ memerlukan informasi lebih banyak tentang partai-partai yang ikut serta dalam Pemilu Legislatif dan Pemilu eksekutif. 
(3) $78 \%$ memerlukan informasi lebih banyak tentang calon anggota legislative (Caleg) yang akan mencalonkan diri.

(4) $79 \%$ memerlukan informasi lebih banyak tentang visi, misi dan program partai.

(5) $71 \%$ memerlukan informasi lebih banyak tentang dimana dan kapan untuk memilih.

(6) $69 \%$ memerlukan informasi lebih banyak tentang proses pemberian suara di surat suara.

(7) $72 \%$ memerlukan informasi lebih banyak tentang proses penghitungan suara alokasi kursi partai.

(8) $72 \%$ memerlukan informasi lebih banyak tentang proses penghitungan suara bagaimana seorang kandidat bisa terpilih.

Sumber Informasi Utama dalam Pemllu 2014

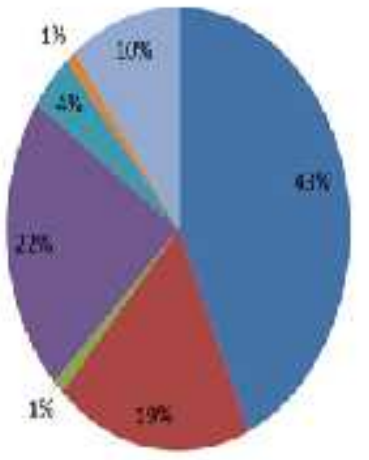

1 1 Tolavi

nz-anita d Uesa

"n $3^{\text {Tamn }}$

a 2 KJ A Acch Burot

infadio

e $61 \mathrm{coter}$

is TKe U arge

Gambar 2. Sumber Informasi utama dalam Pemilu 2014

\section{Persepsi terhadap Lembaga Penyelenggaraan Pemilu yang mandiri dan bebas intervensi}

Mayoritas pemilih (53\%) menyatakan persetujuan terhadap lembaga penyelenggaraan pemilu yang mandiri dan bebas intervensi. Selain itu masih terdapat pemilih (27\%) yang ragu-ragu terhadap hal ini. Badan penyelenggara pemilu dan badan penyelesaian sengketa pemilu - baik yang independen, bentukan pemerintah, maupun gabungan keduanya - harus menaati prinsip dan nilai-nilai demokrasi dan menjalankan fungsinya secara independen, profesional, dan imparsial.

Profesionalisme mencakup penyelenggaraan proses pemilu dengan baik dan tepat waktu sesuai prinsip-prinsip hukum dan etika. Profesionalisme juga menuntut individuindividu yang menangani penyelesaian sengketa pemilu untuk memiliki pemahaman yang baik dan selalu siap untuk bertanggung jawab atas tindakan yang mereka lakukan atau tindakan yang tidak mereka lakukan.

Badan penyelenggara pemilu dan badan penyelesaian sengketa pemilu harus mematuhi prinsip kepastian, legalitas, obyektivitas, independensi, netralitas, dan imparsialitas sehingga mereka dapat diandalkan dan dipercaya dalam menjalankan tugasnya sebagai otoritas pemilu yang dapat mencegah terjadinya sengketa pemilu. Independensi atau kewenangan lembaga yang diberikan tanggung jawab 
menyelenggarakan dan melaksanakan proses pemilu merupakan indikasi bahwa tindakan yang mereka lakukan merupakan bagian dari mandat mereka yang diatur oleh undangundang, tanpa adanya campur tangan pemerintah atau partai politik.

Ketentuan dan mekanisme yang diadopsi berdasarkan konteks dan tradisi lokal - yang sesuai dengan prinsip dan nilai demokrasi yang dianut bersama oleh warga - dapat mencegah terjadinya sengketa pemilu. Agar dapat bekerja independen, profesional, dan imparsial, anggota badan penyelenggara pemilu dan badan penyelesaian sengketa pemilu perlu mendapat jaminan kerja, gaji yang menarik, dan imunitas dari tuntutan pidana. Sebaiknya mereka juga dilarang untuk menduduki posisi tertentu pada saat atau tidak lama setelah mereka menyelesaikan masa tugas di kedua lembaga tersebut.

Badan penyelenggara pemilu dan badan penyelesaian sengketa pemilu harus transparan dalam membuat keputusan. Mereka harus mampu menjelaskan keputusan yang telah dibuat kepada pihak-pihak yang terlibat dan masyarakat umum. Keterbukaan ini dapat mencegah manipulasi informasi yang dapat mengakibatkan berkurangnya legitimasi proses pemilu atau melemahnya kewenangan mereka dalam penyelenggaraan pemilu.

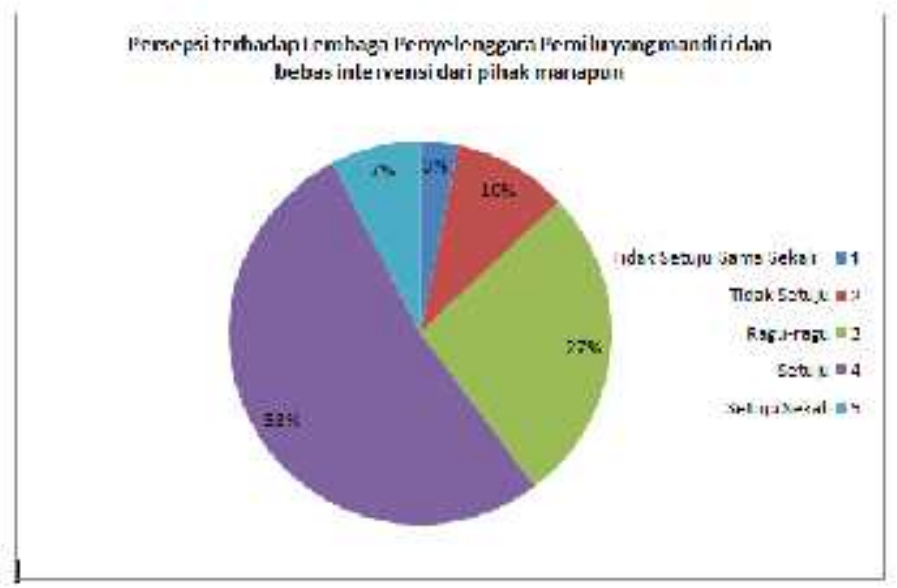

Gambar 3. Persepsi terhadap Lembaga Penyelenggara Pemilu Legislatif 2014

\section{Persepsi terhadap Pemilu Legislatif 2014 dilaksanakan secara langsung, umum, bebas, rahasia, jujur dan adil.}

Mayoritas pemilih (43\%) menyatakan persetujuan terhadap Pemilu Legislatif 2014 dilaksanakan secara langsung, umum, bebas, rahasia, jujur dan adil tetapi masih berimbang sebanyak $42 \%$ menyatakan keraguan. Pada era reformasi mulai berkembang asas pemilu "luberjurdil" singkatan dari langsung, bebas, rahasia, jujur dan adil. Langsung berarti pemilu dilaksanakan secara langsung dan serentak diseluruh wilayah Indonesia. Bebas artinya setiap warga negara yang telah memiliki hak pilih dalam pemilu bebas memberikan hak pilihnya tanpa ada suatu paksaan dari pihak lain.

Rahasia maksudnya bagi peserta pemilu legislatif dan pemilu eksekutif eksekutif dijamin atas kerahasiaannya mengenai pilihannya yang bertujuan untuk menghindari hal-hal yang tidak diinginkan misalnya pertikaian antar warga sehingga menyebabkan perpecahan dalam lingkungan masyarakat.

Jujur mengandung makna bahwa pemilihan umum harus dilakukan sesuai dengan aturan yang berlaku. Hal ini bertujuan untuk memastikan bahwa setiap warga negara yang 
memiliki hak dapat memilih sesuai dengan kehendaknya dan setiap suara pemilih memiliki nilai yang sama untuk menentukan wakil rakyat yang akan terpilih. Asas adil mengandung makna perlakuan yang sama atau adil terhadap peserta pemilu legislatif dan pemilu eksekutif, dan tidak ada pengistimewaan ataupun diskriminasi terhadap peserta atau pemilih tertentu. Asas langsung, bebas, rahasia, jujur dan adil berlaku untuk pemilih ataupun peserta pemilu, dan juga penyelenggara pemilu.

Adapun berkenaan dengan partisipasi masyarakat dalam pengawasan Pemilu Eksekutif ada empat hal yang perlu dilakukan, yaitu:

1. Perluasan jaringan pengawasan pada kelompok-kelompok strategis;

2. Pengembangan model pengawasan partisipatif (community based supervisory mechanism);

3. Pengembangan Pusat Data dan Pembelajaran Pengawasan Pemilu (Empowerment and Data Election Supervisory Center/EDESC);

4. Pengembangan strategi kampanye pengawasan Pemilu yang mampu mendorong menguatnya tingkat partisipasi masyarakat dalam pengawasan dan pelaporan pelanggaran Pemilu.

Selain strategi-strategi yang perlu disusun guna terselenggaranya pemilu yang bebas, rahasia, jujur dan adil perlu juga diperhatikan masalah Etika dalam berpolitik.Menurut Kamus Besar Bhs. Indonesia (1995), Etika adalah Nilai mengenai benar dan salah yang dianut suatu golongan atau masyarakat.Secara subtantif pengertian etika politik tidak dapat dipisahkan dengan subyek sebagai pelaku etika yaitu manusia.

Oleh karena itu etika politik berkait erat dengan bidang pembahasan moral. Hal ini berdasarkan kenyataan bahwa pengertian moral senantiasa menunjuk kepada manusia sebagai subyek etika. Maka kewajiban moral dibedakan dengan pengertian kewajibankewajiban lainya, karena yang dimaksud adalah kewajiban manusia sebagai manusia.

Walaupun dalam hubunganya dengan masyarakat bangsa maupun negara, Etika politik tetap meletakkan dasar fundamental manusia sebagai manusia. Dasar ini lebih meneguhkan akar etika politik bahwa kebaikan senantiasa didasarkan kepada hakikat manusia sebagai makhluk yang beradab dan berbudaya.

Prinsip-prinsip demokrasi modern semestinya menjunjung tinggi dan menempatkan etika politik sebagai bagian dari pengawasan praktek pelaksanaan pemilu yang dilakukan oleh partai politik dalam strategi kampanye politiknya. 


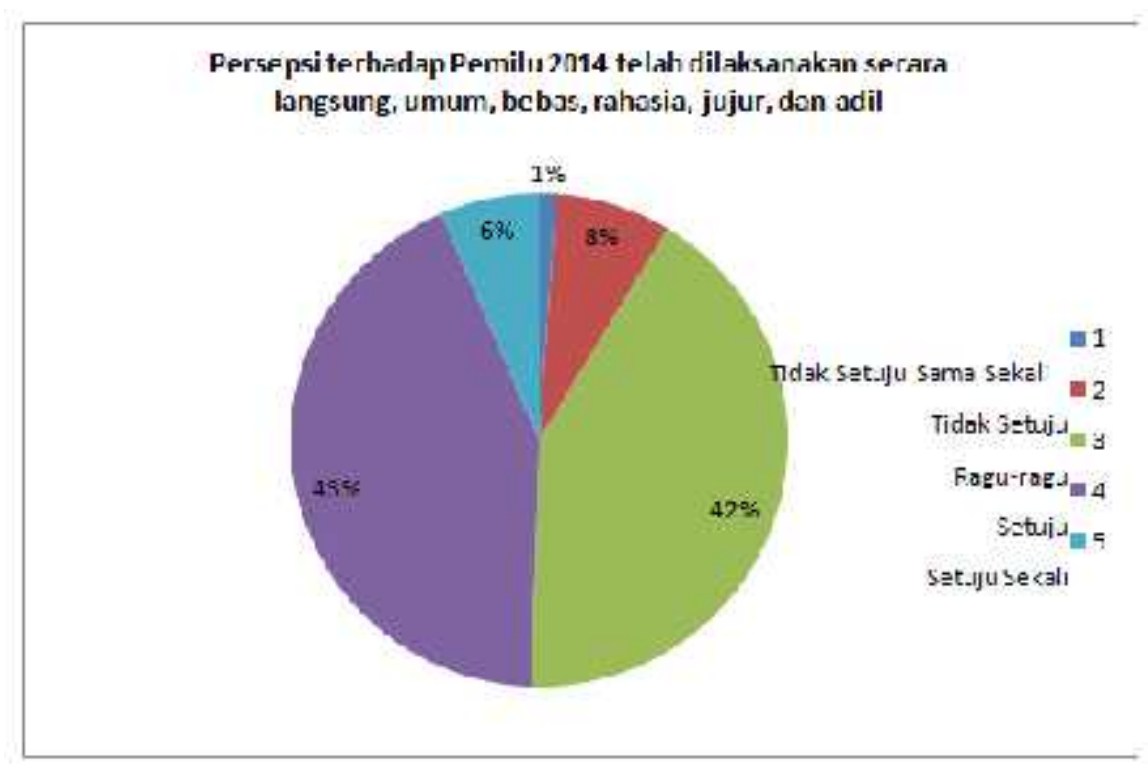

Gambar 4. Persepsi terhadap Pemilu Legislatif 2014 telah dilaksanakan secara langsung, umum, bebas, rahasia, jujur dan adil.

\section{E. Persepsi terhadap Penyelenggara Pemilu Legislatif 2014 secara demokratis, prosedural, transparan dan akuntabel}

Mayoritas pemilih (46\%) menyatakan persetujuan terhadap pemilu legislatif 2014 dilaksanakan secara demokratis, prosedural, transparan dan akuntabel tetapi masih berimbang sebanyak 39\% menyatakan keraguan. Pada abad 21 (era globalisasi) ditandai kemajuan teknologi informasi, dimana perkembangan dan dinamika suatu masyarakat dapat diakses oleh masyarakat lainnya diberbagai belahan penjuru dunia. Konsekuensinya, penyelenggaraan pemilu legislatif sebagai wahana keikut-sertaan masyarakat secara aktif dalam mempengaruhi dan menentukan arah kebijakan haluan negara, adalah suatu keniscayaan bahwa akses informasi kepada masyarakat luas tentang penyelenggaraan pemilu selain berlandaskan asas demokratis dan prosedural, juga harus diimbangi bahwa pemilu dilakukan dengan proses transparansi dan prosedural. 


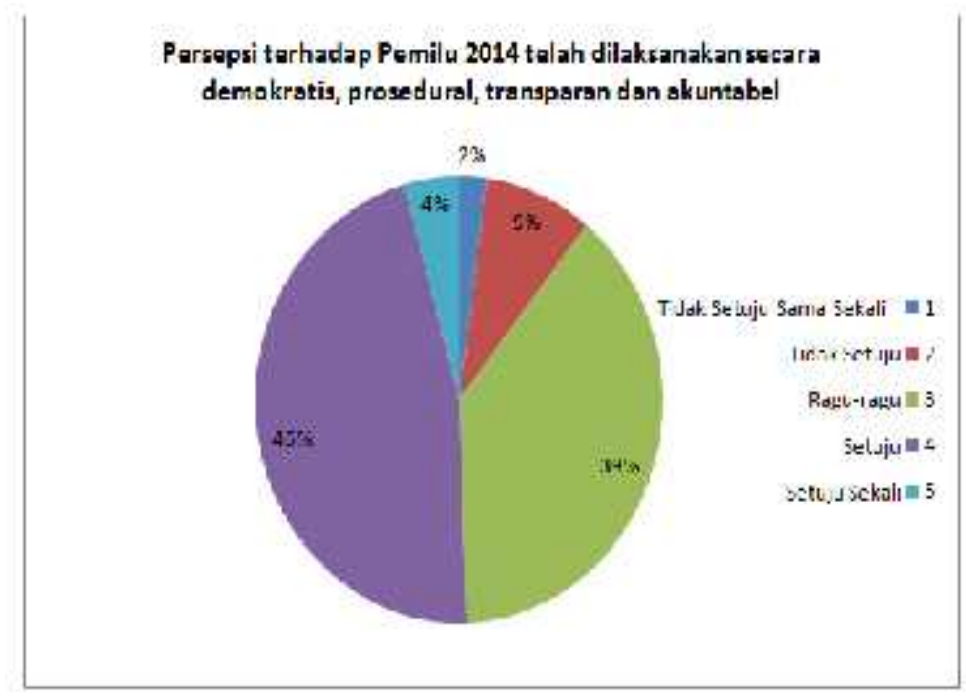

Gambar 5. Persepsi terhadap Penyelenggara Pemilu 2014 secara demokratis, prosedural, transparan dan akuntabel

\section{F. Persepsi terhadap Posisi Pemerintah}

Mayoritas pemilih (46\%) menyatakan persetujuan terhadap Posisi Pemerintah dan jajarannya menjaga integritas dan netralitas tetapi masih berimbang sebanyak $39 \%$ menyatakan keraguan. Pelaksanaan pemilu yang demokratis senatiasa menjunjung tinggi prinsip-prinsip integritas dan netralitas. Sistem pemerintahan demokratis, senantiasa melakukan perbaikan regulasi penyelenggaraan pemilu, untuk meminimalisir terjadinya pelanggaran terhadap pelaksanaan pemilu yang tidak memiliki integritas dan netralitas. Posisi pemerintah dan jajarannya diharapkan untuk selalu menjaga prinsip-prinsip tersebut, sehingga penyelenggaraan pemilu berjalan dengan baik. Mesin birokrasi yang dimliki pemerintah dari pusat hingga tingkat paling bawah yaitu desa, dan menyentuh langsung urat nadi masyarakat, sehingga posisi ini sangat rentan untuk dilakukan penyimpangan, baik dalam bentuk melakukan intervensi maupun mobilisasi terhadap masyarakat untuk memberikan suaranya kepada yang ditentukan. Sehingga harapan terselenggaranya pemilu yang memiliki integritas dan netralitas tidak akan pernah terwujudkan. 


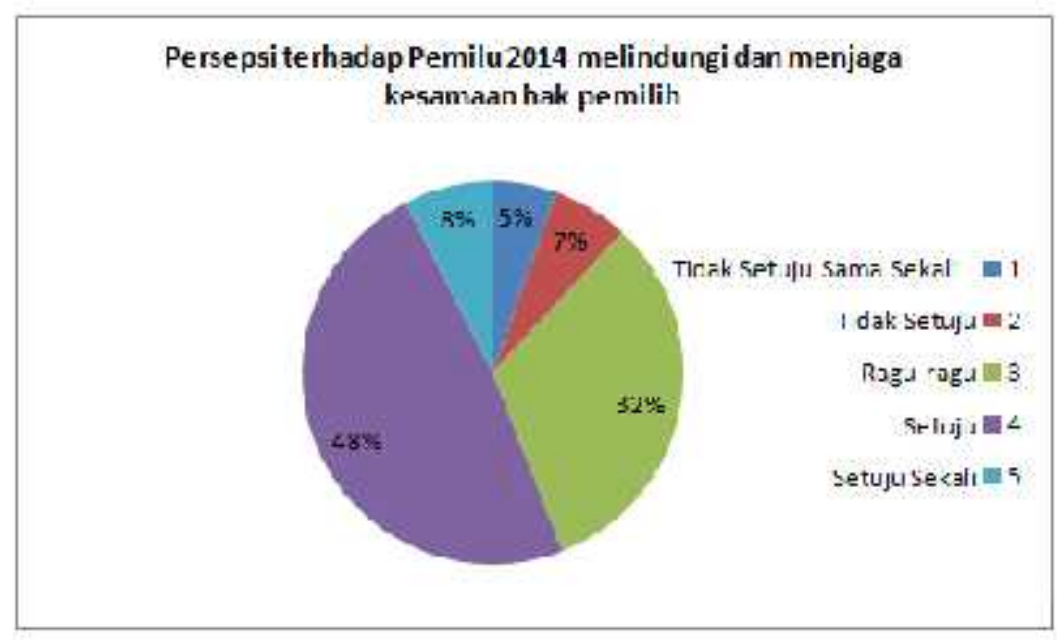

Gambar 6. Persepsi terhadap Posisi Pemerintah

\section{G. Persepsi terhadap Pemilu Legislatif 2014 yang memperhatikan hak individu}

Mayoritas pemilih (48\%) menyatakan persetujuan terhadap Pemilu Legislatif 2014 yang melindungi dan menjaga kesamaan hak pemilih. Tetapi masih ada keraguan pemilih (32\%) bahwa penyelenggaraan pemilu legislatif 2014 dapat melindungi dan menjaga kesamaan hak pemilih. Dalam sistem pemerintahan yang demokratis, kekuasaan sepenuhnya ada di tangan rakyat, artinya suara rakyatlah yang menentukan masa depan pemimpinnya. Pemerintahan yang dibentuk benar-benar berdasarkan keinginan dan kepercayaan rakyat. Penyelenggaraan pemilu legislatif diharapkan dapat menjamin kesamaan hak pemilih dalam menyalurkan keinginan dan kepercayaan.

Sistem pemilu yang demokratis senantiasa menjunjung tinggi dan memberikan jaminan terhadap hak individu yang dimiliki masyarakat dalam keikutsertaannya mengikuti proses penyelenggaraan pemilu, sejak dari terdaftarnya sebagai pemegang pemilik suara hingga saat menentukan pilihannya dibilik suara. Penyelenggaran pemilu harus dibebaskan dari praktek pengekangan terhadap hak individu yang dimiliki masyarakat, seperti intimidasi. 


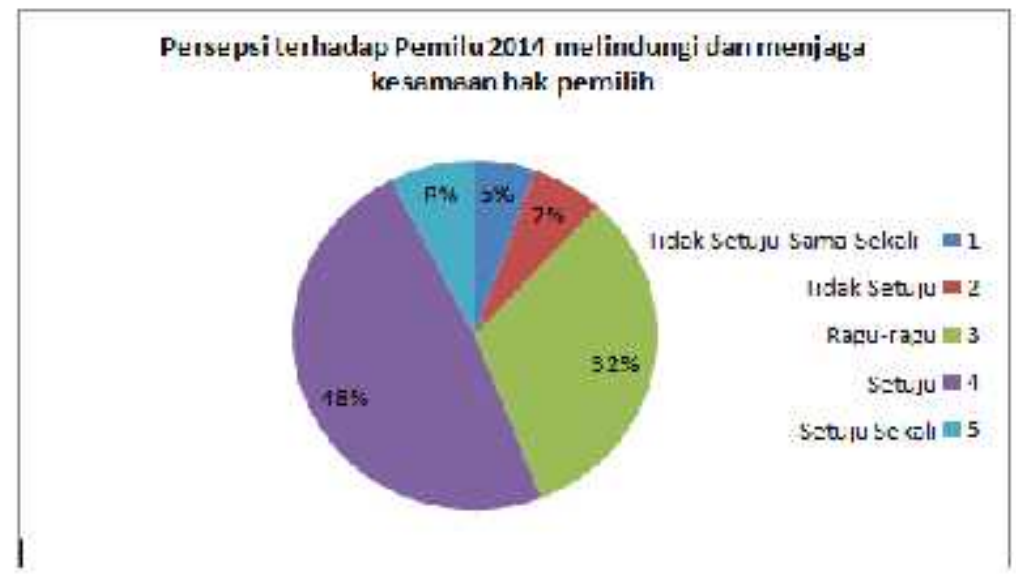

Gambar 7. Persepsi terhadap Penyelenggara Pemilu 2014 melindungi dan menjaga kesamaan hak pemilih

\section{H. Persepsi terhadap Perbaikan Pemilu}

Mayoritas pemilih (83\%) menyatakan perlunya perbaikan terhadap penyelenggaraan Pemilu kedepan. Penyelenggaraan pemilu, sebagai wadah pesta demokrasi, tidak saja sebagai kegiatan rutinitas 5 tahunan, tetapi memberikan dampak positif bagi terciptanya pelaksanaan pemilu legislatif yang demokratis. Tingginya ekspektasi masyarakat agar penyelenggaraan pemilu dapat mengalami perbaikan pada setiap penyelenggaraan pemilu di tahun-tahun mendatang.

Kajian Santoso (2006) menyimpulkan ada empat masalah perbaikan pemilu, yaitu tindak pidana pemilu, pelanggaran administrasi pemilu, perselisihan administrasi pemilu, dan perselisihan hasil pemilu. Apa yang disebut dengan sengketa dalam penyelenggaraan pemilu tidak pernah terjadi dalam praktik pemilu sehingga keberadaannya dalam undangundang pemilu bisa ditiadakan. Sebagai gantinya, kajian ini menemukan satu masalah hukum yang disebut perselisihan administrasi pemilu, berupa kesempatan bagi pihak-pihak yang merasa dirugikan oleh keputusan penyelenggara pemilu untuk mengajukan keberatan kepada penyelenggara pemilu di atasnya atau kepada lembaga peradilan, agar meninjau keputusan yang dirasa merugikan tersebut.

Tindak pidana pemilu adalah perbuatan melanggar ketentuan-ketentuan pidana pemilu yang diancam dengan sanksi pidana sebagaimana diatur dalam undang-undang Pemilu. Pelanggaran administrasi pemilu adalah perbuatan melanggar ketentuan peraturan perundangan yang tidak diancam dengan sanksi pidana, khususnya pelanggaran terhadap ketentuan, persyaratan, kewajiban, perintah, dan larangan sebagaimana diatur dalam undang- undang dan peraturan Pemilu lainnya. 
Perselisihan administrasi pemilu adalah perselisihan yang ditimbulkan oleh keputusan atau tindakan penyelenggara pemilu yang dianggap merugikan pihak tertentu, dalam hal ini adalah warga negara (yang mempunyai hak pemilih dan pemilih), partai peserta pemilu, bakal calon anggota legislatif, calon anggota legislatif, bakal calon presiden/wakil presiden dan bakal calon kepala daerah/wakil kepala daerah, serta calon presiden/wakil presiden dan calon kepala daerah/wakil kepala daerah, yang terjadi dalam tahapan-tahapan Pemilu.

Perselisihan hasil pemilu adalah perselisihan yang ditimbulkan oleh keputusan penyelenggara pemilu tentang hasil pemilu yang dianggap merugikan pihak tertentu, dalam hal ini peserta pemilu perseorangan (untuk memilih DPD), peserta pemilu partai politik (untuk memilih DPR dan DPRD), calon presiden dan wakil presiden, serta calon kepala daerah dan wakil kepala daerah, yang terjadi pada tahapan penetapan hasil pemilu.

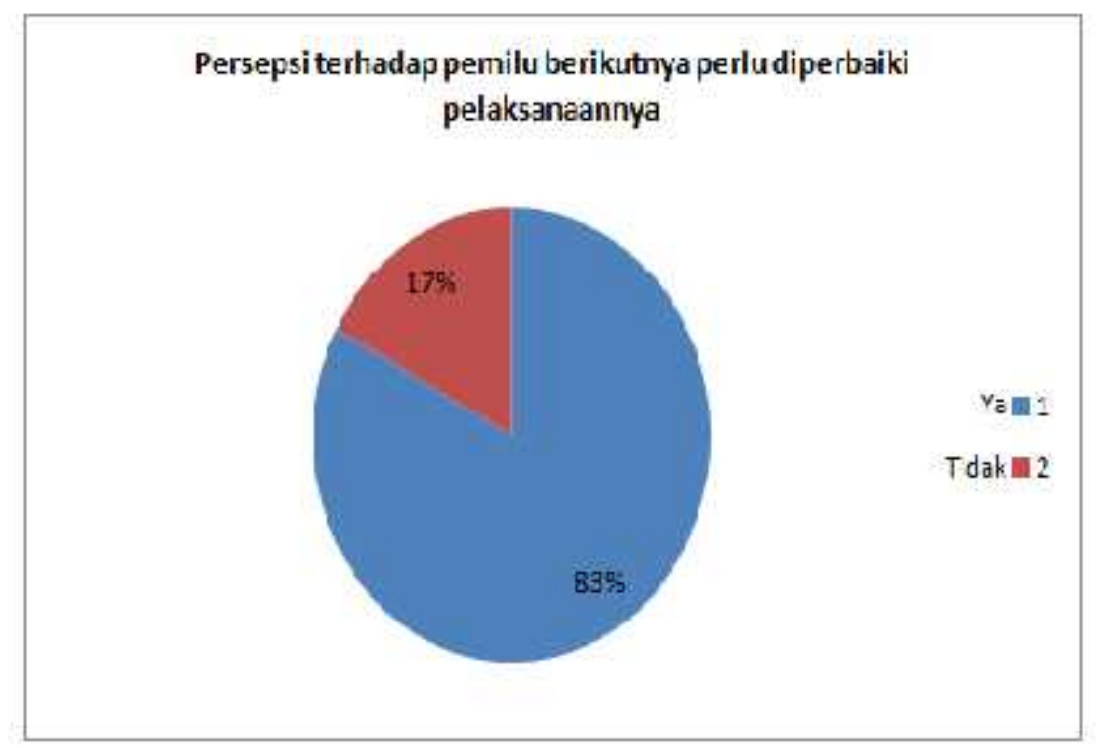

Gambar 8. Persepsi terhadap perbaikan pelaksanaan Pemilu

\section{Pilihan Partai pada Pemilu Legislatif 2009 dan 2014}

Pada penyelenggaraan Pemilu Legislatif 2009, responden sedikit lebih banyak memilih partai lokal (55\%) dibandingkan partai nasional (45\%). Berbeda pada Pemilu Legislatif 2014, responden jauh lebih banyak memilih partai nasional $(63 \%)$ dibandingkan partai lokal (37\%). 


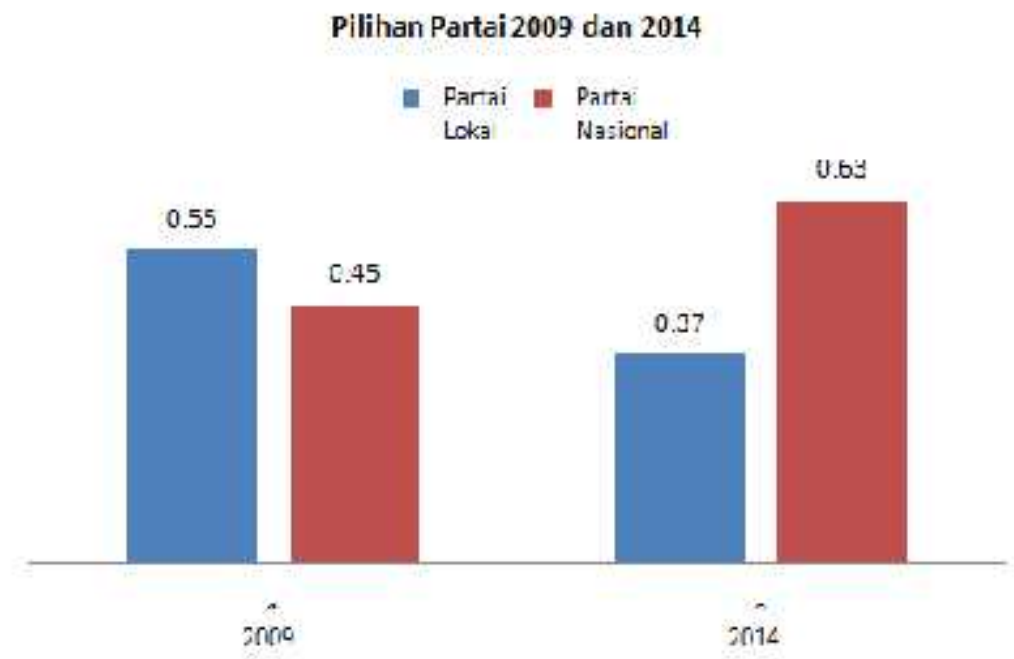

Gambar 9. Pilihan Partai Politih pada Pemilu 2009 dan 2014

\section{KESIMPULAN DAN SARAN}

\section{Kesimpulan}

1. Partisipasi pemilih masih cukup tinggi dengan kesadaran sendiri (75\%) berpartisipasi dalam Pemilu Legislatif 2014.

2. Persepsi persetujuan pemilih belum terlalu tinggi (diantara $43 \%-53 \%$ ) terhadap (1) lembaga penyelenggaraan pemilu legislatif yang mandiri dan bebas intervensi, (2) Pemilu Legislatif 2014 dilaksanakan secara langsung, umum, bebas, rahasia, jujur dan adil, (3) Pemilu Legislatif 2014 dilaksanakan secara demokratis, prosedural, transparan dan akuntabel, (4) posisi pemerintah dan jajarannya menjaga integritas dan netralitas dan (5) Pemilu Legislatif 2014 yang melindungi dan menjaga kesamaan hak pemilih,

3. Pilihan terhadap partai politik lokal pada Pemilu Legislatif 2014 menurun (pemilih sebesar 37\%) dibandingkan pada Pemilu 2009 (pemilih sebesar 55\%). Sementara pada partai nasional meningkat dari pemelih sebesar $45 \%$ menjadi $63 \%$.

4. Responden berasal dari $65 \%$ pria dan $35 \%$ wanitaUsia responden pemilih masih produktif dengan rata-rata 37 tahun dan pendapatan rata-rata Rp. 2.081.000,-. Televisi masih sumber utama bagi pemilih (43\%) dalam mencari informasi terkait Pemilu Legislatif 2014. Sisanya sebanyak 22\% dan 19\% melalui KPU dan panitia penyelenggara di tingkat desa.

\section{Saran}

1. Penelitian terkait Pemilu Legislatif 2014 masih relevan untuk mengetahui persepsi pemilih dari perbedaan geografi (pemilih dari daerah rural dan urban) dan status sosial ekonomi (pendidikan dan pendapatan).Hal ini dapat berimplikasi terhadap perbaikan 
dalam penyelenggaraan Pemilu dari sisi sumber informasi utama yang dicari pemilih dan peran KPU mulai dari tingkat kabupaten sampai desa.

2. Penelitian masih perlu dilanjutkan dengan analisis korelasi antara pilihan partai politik dan status sosial ekonomi (jenis kelamin, domisili, pekerjaan dan pendapatan) sehingga dapat menjadi informasi yang bermanfaat bagi partai politik lokal maupun nasional dalam strategi sosialisasi dan pemenangan pada Pemilu berikutnya.

\section{REFERENSI}

Budiardjo, Miriam.2009. Dasar-Dasar Ilmu Politik. Jakarta.PT. Gramedia Pustaka Utama

Chehabi, Houchang Esfandiar \& Juan José Linz, Sultanistic Regimes (1988), Johns Hopkins University Press, Baltimore.

David Beetham dan Kevin Boyle, Demokrasi, (Yogyakarta: Kanisius, 2000)

Liddle, R. William. 2000. Memastikan Arah Baru Demokrasi. Jakarta FISIP UI.

Milbrath, Lester. 1965. Political Partisipation, How and Way, Do get Involved in Politics. Chicago: Rand McNally.

Maleong, Lexi J, 2002. Metode Penelitian Kualitatif untuk Pemula, Bandung : Remaja Rosda Karya, Bandung: 2002

Santoso, Topo, Kajian Kebijakan : Sistem Penegakan Hukum Pemilu, 2006 Tim Peneleiti PERLUDEM, Jakarta 